\title{
Lehetőségek és buktatók a SARS-CoV-2-antigén és az ellene termelt antitestek kimutatásában
}

\author{
Medgyaszai Melinda dr. ${ }^{1}$ - Péterfi Zalán dr. $^{2}$ - Valkó Anna dr. ${ }^{3}$ \\ ${ }^{1}$ Országos Korányi Pulmonológiai Intézet, Budapest \\ ${ }^{2}$ Vascular Diagnostics Kft., Budapest \\ ${ }^{3}$ Állatorvostudományi Egyetem, Budapest
}

\begin{abstract}
A koronavírus-betegség 2019 (COVID-19)-pandémia komoly kihívás elé állította nemcsak a mikrobiológiai laboratóriumokat, hanem az eredmények interpretálásában a klinikumban dolgozó kollégákat is. Az orvostudomány specializált világában az immunológiai és a fertőző betegségekkel kapcsolatos ismeretek az antimikrobás terápiás megoldások sikeressége, valamint a széles körú vakcináció miatt az idők folyamán számos szakterületen háttérbe szorultak, felfrissítésük sürgető és elengedhetetlen része a pandémiával való megküzdésnek. A diagnosztikai vizsgálatok fontos eszközei a járvány megfékezésének, illetve a betegek ellátásának, azonban a vírus és az emberi szervezet interakciójának megértése elengedhetetlenül szükséges a korrekt epidemiológiai és gyógyászati véleményalkotáshoz. Jelen cikkünk az orvosi gyakorlat számára foglalja össze a súlyos akut légzőszervi szindrómát okozó koronavírus-2 (SARS-CoV-2) kimutatására, valamint az immunrendszer specifikus immunválaszának szerológiai vizsgálatára irányuló, gyakorlatban használatos módszereket, azok helyét, szerepét és értékelésük szempontjait a tudomány jelen állása szerint.

Orv Hetil. 2021; 162(15): 563-570.
\end{abstract}

Kulcsszavak: SARS-CoV-2, COVID-19, antigének, ellenanyagok, diagnosztikai tesztek, immunválasz

\section{Possibilities and pitfalls of virus antigen and antibody detection of SARS-CoV-2}

The coronavirus disease 2019 (COVID-19) pandemic posed a serious challenge not only for microbiology laboratories, but also for the clinicians in interpretation of the results. In the specialized world of medicine, knowledge of immunological and infectious diseases has been relegated to the background in many disciplines over time due to the success of antimicrobial therapies and widespread vaccination, so updating them is an urgent and essential part of the fight against the pandemic. Diagnostic tests are important tools for controlling the epidemic and caring for patients, but understanding the interaction between the virus and the human body is essential to form a correct epidemiological and medical opinion. This paper summarizes the medical methods for the detection of severe acute respiratory syndrome coronavirus 2 (SARS-CoV-2) and the serological testing of the specific immune response of the immune system, their place, role and criteria of their evaluation according to current scientific knowledge.

Keywords: SARS-CoV-2, COVID-19, antigens, antibodies, diagnostic tests, immune response

Medgyaszai M, Péterfi Z, Valkó A. [Possibilities and pitfalls of virus antigen and antibody detection of SARS-CoV-2] Orv Hetil. $2021 ; 162(15): 563-570$.

(Beérkezett: 2021. február 11.; elfogadva: 2021. február 18.)

\section{Rövidítések}

ACE2 = (angiotensin converting enzyme 2) az angiotenzinkonvertáló enzim 2-es típusa; $\mathrm{ADCC}=$ (antibody-dependent cell cytotoxicity) ellenanyag-dependens sejt-citotoxicitás; ADE = (antibody-dependent enhancement $)$ antitestfüggő erősítés;
$\mathrm{CD}=$ (cluster of differentiation $)$ differenciálódási klaszter; $\mathrm{CE}$ $=($ Conformité Européenne $)$ európai megfelelőség; CLIA = (chemiluminescence immunoassay) kemilumineszcens immunteszt; COVID-19 = (coronavirus disease 2019) koronavírusbetegség 2019; CRISPR = (clustered regularly interspaced 
short palindromic repeats) halmozottan előforduló, szabályos közökkel elválasztott palindromikus ismétlődések; $\mathrm{Ct}=($ cycle threshold) ciklusküszöb; DNS = dezoxiribonukleinsav; ELISA $=($ enzyme-linked immunosorbent assay $)$ enzimhez kötött immunszorbensteszt; FDA = (U.S. Food and Drug Administration) az Amerikai Egyesült Államok Élelmiszer- és Gyógyszerengedélyeztetési Hivatala; FIA = (fluorescence immunoassay) fluoreszcens immunteszt; IFN = interferon; Ig = immunglobulin; LFIA = (lateral flow immunoassay) oldalirányú áramlási immunteszt; IL = interleukin; $\mathrm{MHC}=($ major histocompatibility complex) fó hisztokompatibilitási komplex; PAMP = (pathogen-associated molecular pattern) patogénre jellemző molekuláris mintázat; $\mathrm{PDI}=($ programmed cell death protein 1$)$ programozott sejthalál fehérje- $1 ; \mathrm{POC}=($ point of care $)$ betegágy melletti; $\mathrm{PRR}=$ (pattern recognition receptor) mintázatfelismerô receptor; $\mathrm{RBD}=$ (receptor-binding domain) receptorkötő domén; RNS = ribonukleinsav; rtPCR $=$ (real-time polymerase chain reaction) valós idejü polimeráz-láncreakció; SARS-CoV-2 $=($ severe acute respiratory syndrome coronavirus 2) súlyos akut légzőszervi szindrómát okozó koronavírus-2; $\mathrm{Tc}=$ citotoxikus $\mathrm{T}$-sejt; $\mathrm{Th}=(\mathrm{T}$ helper cell $)$ segítő $\mathrm{T}$-sejt

A koronavírus-betegség 2019 (COVID-19) [1] mikrobiológiai diagnosztikája alapvetôen megegyezik az általános vírusdiagnosztikával: egyrészt a vírusra specifikusan jellemző antigén, másrészt az immunrendszer vírusra adott reakciójának részeként megjelenő antitestek kimutatását célozza meg. A mikrobiológiai laboratóriumi lelet azonban csak egy a számos adat, eredmény közül, melyek értékelése során optimális esetben a klinikus figyelembe veszi a vírus és a beteg jellemzőit, holisztikusan értelmezi a betegség kialakulása és lefolyása során az egyes momentumok jelentőségét. Az adott eset teljes képének áttekintéséhez így elengedhetetlen az alapvető virológiai, immunológiai és labortechnikai ismeretek alkalmazása. A jelen irodalmi áttekintés az ezen ismeretekben való elmélyedéshez kíván közérthetô segítséget nyújtani, a cikk írásának idején elérhető kutatási eredmények fényében.

\section{A vírus útja a szervezetben}

A súlyos akut légzőszervi szindrómát okozó koronavírus-2 (SARS-CoV-2) az emberek között elsősorban cseppfertózéssel terjed, de kisebb partikulák levegőn keresztüli átvitele, valamint ragályfogó tárgyak és a faecalisoralis átvitel potenciális szerepe is felmerült, egyelöre vitatott jelentőséggel [2]. A vírus tehát alapvetôen a légzőszerveken keresztül jut be az emberi szervezetbe, ahol a felületén lévő tüskefehérjével kötődik az angiotenzinkonvertáló enzim-2 (ACE2) receptorral rendelkező sejtekhez, melyekbe a behatolását egyéb gazdasejt-mediátorok - például a neuropilin-1 - is elősegíthetik [3]. Ilyen sejtek az orr-garat üregben is találhatók, de a SARSCoV-2 fó célszerve a tüdő, melyben a szövetképző hámsejtek és a vérérfalak endothelsejtjei mellett az immunrendszer járőröző falósejtjeit, az alveolaris makrofágokat is képes megfertózni. A replikáció, azaz a vírus megsok- szorozódása rendkívül gyorsan lejátszódhat ezekben a sejtekben: az eddigi megfigyelések alapján a vírus ürítése már a tünetek megjelenése előtti pár napban elkezdődhet, majd az első 4., 5. napban éri el a legmagasabb szintet, a későbbiekben jellemzően csökken [4]. A vírusürítés időtartama nagymértékben függ a szervezet védekezőképességétől, immunkompromittált és súlyos betegek esetében jelentősen elhúzódhat. Az egyéni biológiai adottságok és szociális magatartás mellett az eleve magas kockázatú területek (például idősotthon, húsüzem), valamint a nagyobb tömegeket tömörítő helyszínek (zsúfolt tömegközlekedés, éjszakai klubok) járulhatnak hozzá az ún. szuperterjesztéshez [5]. Egy átlagos fertőzött jellemzően 2-3 másik embernek adhatja át a vírust, adott egyénekben viszont - jelenleg ismeretlen okból - a vírusürítés mértéke az átlagot többszörösen meghaladhatja, és ezen személyek több tíz, zsúfolt helyen akár több száz fogékony embert megfertőzhetnek. A SARS-CoV-2-fertózés tehát jelentősen eltérő vírusürítéssel járhat a betegség alatt [6], valamint a fertőzés preés aszimptómás eseteiben is [7], mely számos nehézséget okozhat a vírus kimutatása során, és nem feltétlenül oldható meg még a magas szenzitivitású és specificitású laboratóriumi technikák ismétlésével sem [8].

\section{A SARS-CoV-2 kimutatása}

A jelenleg engedélyezett, a SARS-CoV-2 kimutatására szolgáló diagnosztikai tesztek két csoportra bonthatók: 1) molekuláris diagnosztikai tesztek és 2) antigéntesztek. Ezek az elkülönülő technológiai megközelítések a SARSCoV-2-részecskének az eltérő alkotóit detektálják $[9,10]$.

A molekuláris tesztek a vírus örökítőanyagát, a vírusrészecskében lévő nukleinsavat mutatják ki. Ezekre a tesztekre jellemző, hogy főként klinikai laboratóriumi körülmények között kerülnek kivitelezésre, habár léteznek megoldások a betegágy mellett elvégezhetó, point of care (POC) diagnosztikára is [11].

A molekuláris diagnosztikai tesztek többnyire reverztranszkriptáz valós idejú PCR (rtPCR) technológiát alkalmaznak, de más molekuláris megközelítések, így CRISPR közvetítette detektálás vagy izotermikus amplifikáció felhasználására is vannak példák [12]. A labordiagnosztikában legelterjedtebb rtPCR során először a reverztranszkriptáz enzim dezoxiribonukleinsavvá (DNS) alakítja át a vírus ribonukleinsavát (RNS), majd erről a templátról egy polimeráz enzim ciklikusan másolatokat készít (amplifikáció), közel megkétszerezve a nukleinsav mennyiségét minden ciklusban. A teszt az amplifikáció során képződő nukleinsavat detektálja valós időben, fluoreszcens próbák segítségével. A ciklusküszöb $(\mathrm{Ct})$ az a ciklusszám, amelynél a fluoreszcens jel megkülönböztethető a háttértőll. A Ct-értékek fordítottan arányosak a mintában lévő célnukleinsav mennyiségével, azaz minél alacsonyabb a Ct-szint, annál nagyobb a célnukleinsav mennyisége a mintában. Többszörös amplifikációs ciklusok futtatásával a PCR-teszt még a vírus genetikai anya- 
gának alacsony szintjét is képes érzékelni a beteg mintájában, így ezek a vizsgálatok általában nagyon érzékenyek. Adott tesztrendszertől függően a 35-40-nél kisebb Ctértékeket klinikailag PCR-pozitívnak nyilvánítják. Ezekkel a tesztekkel a COVID-19 esetén a nasopharyngealis minták virális RNS-e mérhetővé válik már a tünetek megjelenése előtti néhány napban, és a tünetes időszak első hetében csúcspontot ér el. A kimutathatóság folyamatosan csökken az 1 . hét után, és a 3. hetet követően a virális RNS általában kimutathatatlanná válik. A klinikai tünetek azonban nem feltétlenül korrelálnak jól a mért Ct-értékekkel. A súlyos kórházi betegeknél kapott Ctértékek sokszor magasabbak, mint az enyhe esetek Ctértékei, és a PCR-pozitivitás a betegség kialakulásától számított 3 héten túl is fennállhat, amikor az enyhe esetek többsége már negatív eredményt hoz. Fontos továbbá megjegyezni, hogy az eredmény csak a vírus-RNS detektálását tükrözi, mely származhat fertőzőképes és elpusztított, akár immunsejtben lévő vírusból is (1.ábra). Az rtPCR-tesztek specificitása közel 100\%, mivel az amplifikációhoz nélkülözhetetlen primerek kialakítása a SARS-CoV-2 genomszekvenciájára specifikus. Amennyiben időnként hamis pozitív eredmények fordulnak elö, annak hátterében általában labortechnológiai hibák és a reagensek, minták szennyeződése áll [11].

$\mathrm{Az}$ antigéntesztek egy vagy több, specifikus fehérjét detektálnak a vírusrészecskéből. A legtöbb antigénteszt betegágy mellett végezhetô POC-teszt, és kevesebb mint egy órán belül eredményt ad, de léteznek olyan megoldások is, amelyek értékeléséhez laboratóriumi háttér kell. Az elterjedt gyorstesztek a SARS-CoV-2-nukleokapszidhoz vagy -tüskefehérjéhez kötődő, specifikus monoklonális antitesteket használnak, és az antigéneket áramláson alapuló (LFIA) vizsgálati formátumban mutatják ki. Ezek a vizsgálatok ugyanazt a kolloid arany nanorészecske stratégiát alkalmazzák, mint amelyet a COVID-19 elleni immunválasz detektálásához használnak, itt azonban a vírus antigénjét felismerő monoklonális antitestek vannak a színreakciót képző nanorészecskéhez kötve [10]. Az rtPCR-hez képest a gyors antigénkimutatási tesztek alacsonyabb érzékenységgel rendelkeznek, ezért a hamis negatív eredmények fokozott kockázata miatt az rtPCRtesztek kiegészítőjeként lehet rájuk tekinteni. Az antigéntesztek általában olcsóbbak és egyszerúbben kivitelezhetők, mint a molekuláris vizsgálatok, így alternatívát nyújthatnak, ha a pandémia során a molekuláris tesztelési kapacitás egy adott régióban nem tud lépést tartani az igénnyel [13]. Szaglási teszteket is bemutattak elektronikus „orr” vagy akár kutya felhasználásával, de ezeket még nem alkalmazzák közvetlenül a betegellátásban $[14,15]$.

\section{A SARS-CoV-2 és az immunrendszer kölcsönhatása}

Az immunrendszer veleszületett és adaptív ágra tagolható, melyek együttmúködése teremti meg a kórokozó elleni hatékony védekezés alapjait [16]. A SARS-CoV-2
- az emberi szervezethez adaptálódott más kórokozókhoz, például az influenzavírusokhoz hasonlóan - befolyásolja az immunvédekezést, saját zavartalan replikációja érdekében beavatkozik ennek folyamataiba, ezzel felborítja annak harmóniáját, s a gazdaszervezetre végzetes következményekkel járó diszharmonikus reakciókat indít el, az immunrendszer mindkét részét befolyásolva: fokozza a gyulladást, miközben visszafogja az adaptív immunválaszt [17].

Az azonnali válaszreakció a veleszületett immunrendszer sajátja, melyet a szövetekben testszerte vándorló makrofágok kiválóan biztosítanak [16], ezért a SARSCoV-2 és a veleszületett immunrendszer kapcsolatát ezen sejtek segítségével mutatjuk be. A makrofágok a szervezet fó takarítósejtjeinek is tekinthetók: bekebeleznek bármely okból szétesett sejteket, és hozzájárulnak a szövetek regenerációjához is. Amennyiben a veszélyt jelző sejttörmelék mellett patogénre jellemző molekuláris mintázatot (PAMP) is felismernek mintázatfelismerő receptoraik (PRR) segítségével, jelátvivő molekulákat kezdenek termelni az immunválasz beindításához. A PAMP nem specifikus az adott kórokozóra, viszont a jellegét (extra- vagy intracelluláris) meghatározhatja, így a makrofágok vírusfertőzés hatására gyulladáskeltő citokinek - például interleukin-1 (IL-1) és IL-6 - mellett a celluláris immunválaszt fokozó interferont (IFN $\alpha$ ) fognak termelni. Emellett a makrofágok antigénprezentáló sejtként közvetlenül is aktiválják az adaptív immunrendszer sejtjeit a fagocitált kórokozó fehérjéinek fó hisztokompatibilitási komplex (MHC) révén történó bemutatásával. Ezen általános folyamatokba (1.ábra, A) a SARS-CoV-2 több ponton is beleavatkozhat, kialakítva egy diszharmonikus reakciót (1. ábra, $B$ ). A makrofágokon az ACE2 mellett a SARS-CoV-2-fertőzés másik bizonyított receptoraként szolgáló CDI47 is megtalálható, melyeket kihasználva a SARS-CoV-2 terjedéséhez akár maguk az immunsejtek is hozzájárulhatnak, bár egyelöre nem ismert, hogy a kimutatott vírus fagocitózis vagy aktív fertőzés következményeként kerülhet a makrofágokba [18]. A vírus a bejutási módjától függetlenül viszont csökkenti az IFN $\alpha$-nak és jelentősen megnöveli a proinflammatorikus citokineknek a termelését, mely következményes citokinviharhoz és súlyos COVID-19 kialakulásához vezethet. Könnyen értelmezhetó, hogy az ily módon elhatalmasodó természetes immunválasz és gyulladás a tüdő területén a kialakuló funkciócsökkenés miatt életveszélyes „szőnyegbombázássá” alakulhat, ahol a vírus közvetlen károsító hatása mellett immár nem elhanyagolható az önkárosító mechanizmus sem.

Az adaptív immunválaszban részt vevő T- és B-sejtek aktivációja a természetes immunreakció kialakulásakor már elkezdődik az antigénprezentációval, de a folyamat időigényessége miatt ez a kórokozó-specifikus válasz csak később lesz hatásos [16]. A T-sejt-szubpopulációk közül a segítő T-sejtek (Th-sejtek) az immunválasz karmesterei, citokintermelésük révén befolyásolják az immunsejtek és számos egyéb sejt múködését, valamint 


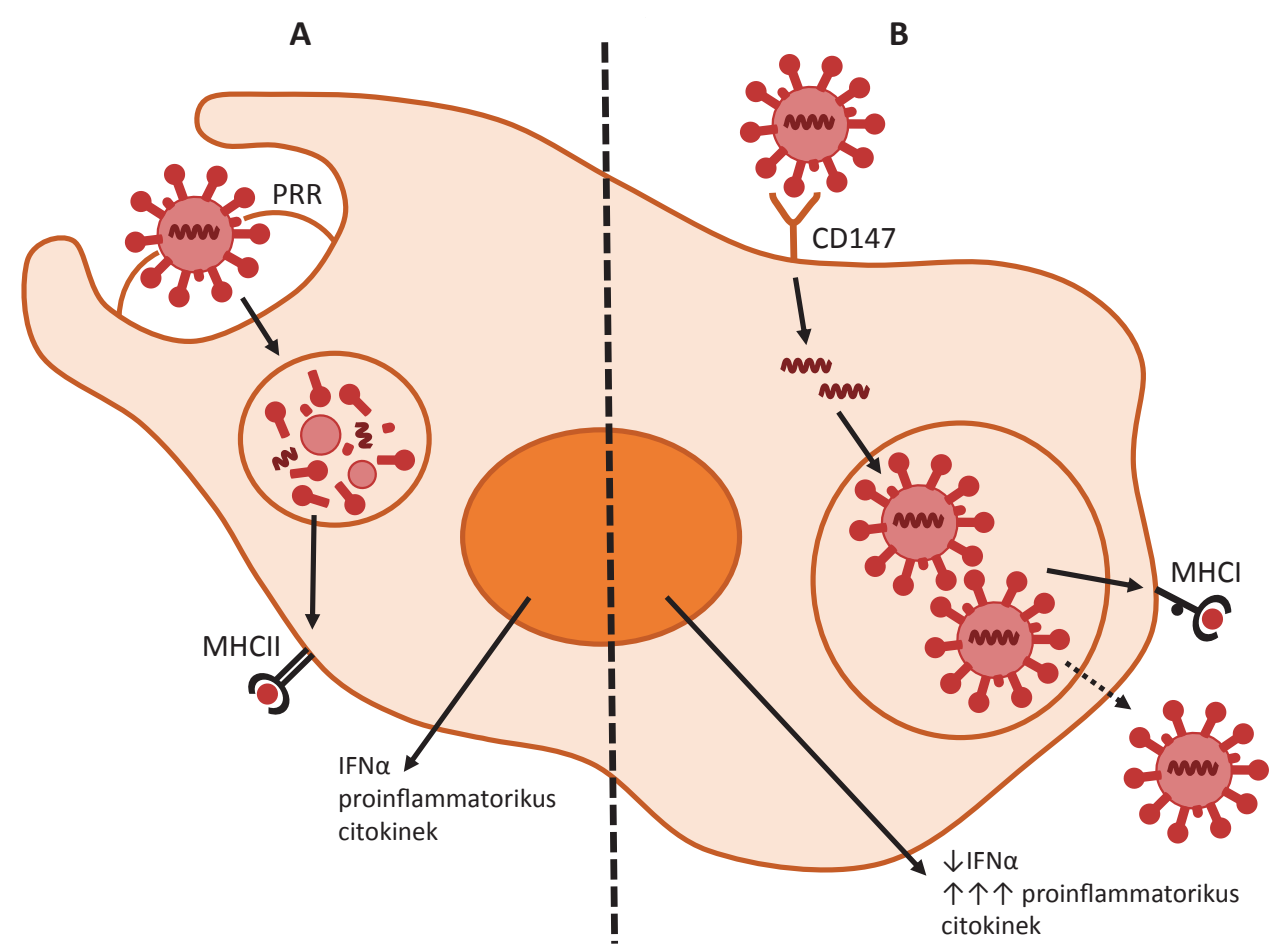

1. ábra $\quad$ Egy makrofág és a SARS-CoV-2 lehetséges kölcsönhatásai

A Fagocitózis. A makrofág PRR segítségével felismeri a PAMP-ot, majd bekebelezi és eliminálja a kórokozót, melynek fehérjéit MHCII-n keresztül prezentálja az adaptív immunrendszer sejtjei számára. A felismert vírus hatására a makrofág gyulladáskeltő citokinek mellett antivirális anyagokat $(\mathrm{IFN} \alpha)$ is termel

B Fertőzés. A SARS-CoV-2 CD147 receptoron keresztül megfertőzheti a makrofágot, mely a vírusfehérjéket MHCI-en prezentálja, és hozzájárulhat a vírus replikációjához és ürítéséhez. A fertőzött sejt kevesebb IFN $\alpha$-t és jelentősen több gyulladáskeltő citokint termel

CD147 = differenciálódási klaszter-147; IFN $\alpha=$ interferon-alfa; $\mathrm{MHC}=$ fó hisztokompatibilitási komplex; PAMP = patogénre jellemző molekuláris mintázat; PRR = mintázatfelismerő receptor; SARS-CoV-2 = súlyos akut légzőszervi szindrómát okozó koronavírus- 2

aktiválják a B-sejteket. A prezentált antigéntől függően különböző típusaik aktiválódnak nagyobb mértékben, melyek közül intracelluláris kórokozók esetén a celluláris immunválaszt fokozó Thl-sejttípus dominál. A celluláris immunválasz fó effektor sejtjei a citotoxikus T-sejtek (Tc-sejtek), melyek eliminálják a fertőzött sejteket apoptózisindukció vagy citolízis révén. A Tc-sejtek a kórokozó fehérje MHCI-en történő prezentációja révén ismerik fel a fertőzött sejteket, így a makrofágok „szőnyegbombázó” mechanizmusával szemben egy nyomkövető rakéta célratörésével képesek azokat likvidálni (2. ábra, $A$ ). A SARS-CoV-2-fertőzés hatására azonban mind a Th-, mind a Tc-sejtek mennyisége szignifikánsan lecsökken, melyben szerepe lehet a felborult citokintermelésnek, beleértve a magas arányú gyulladáskeltő (például IL-6) és immunszuppresszív (IL-10) citokineket is [19]. Ezenfelül a fennmaradó kevés T-sejten kifejezett a kimerülést jelző programozott sejthalál fehérje-1 (PD-1) expressziója, ami csökkent T-sejt-funkcióhoz és következményes zavartalan vírusreplikációhoz vezethet (2. ábra, B).

A T-sejtek a celluláris immunitás mellett a humorális immunválasz kialakításához is nélkülözhetetlenek, mely extracelluláris kórokozók esetén domináns, de a vírusok elleni védekezésben is fontos szerepet játszik [16]. A humorális vagy ellenanyag közvetítette immunválasz a plaz- masejtek által termelt antitesteken alapul. A folyamat a celluláris immunválaszhoz hasonlóan antigénprezentációval kezdődik, melyet maguk a B-sejtek is végezhetnek, de aktivációjukhoz szükségük van a T-sejtek stimulációjára is. Az aktivált B-sejtek plazmasejtekké differenciálódhatnak, melyek immunglobulin(Ig)-gyárként múködnek. Először mindig IgM-termelő plazmasejtek keletkeznek, melyek a később megjelenő IgG-vel szemben még kevésbé specifikusak az adott kórokozóra, de képesek lehetnek azt neutralizálni, és hatékonyabban aktiválják a komplementrendszert. Az IgA a nyálkahártyákon megjelenő specifikus antitest, mely már a bejutás helyén képes lehet megfékezni a kórokozókat, míg az IgG a vér leggyakoribb antitestje. A SARS-CoV-2 a legtöbb fertőzött emberben kiváltja mindhárom antitest képződését, viszont jelentős különbségek mutatkoznak az ellenanyagok mennyiségében: súlyos COVID-19 esetén sokkal magasabb antitestszinteket figyeltek meg IgM és IgG tekintetében is [20]. A magas - és IgG esetén ráadásul későn kezdődő - antitesttermelés azonban kontraproduktívvá válhat, a neutralizáció és az ellenanyag-dependens sejt-citotoxicitás (ADCC) mellett a nagy mennyiségú ellenanyag hozzájárulhat káros folyamatokhoz is (3. ábra). Ilyen folyamat az antitestfüggő erősítés (ADE), mely alapvetően nem neutralizáló anti- 


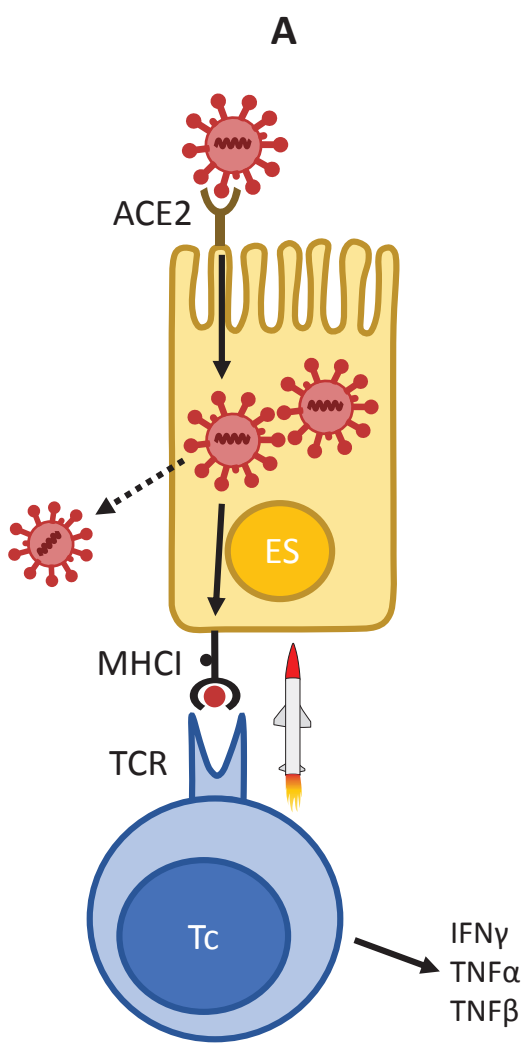

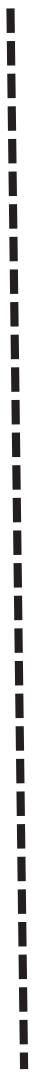

B

!

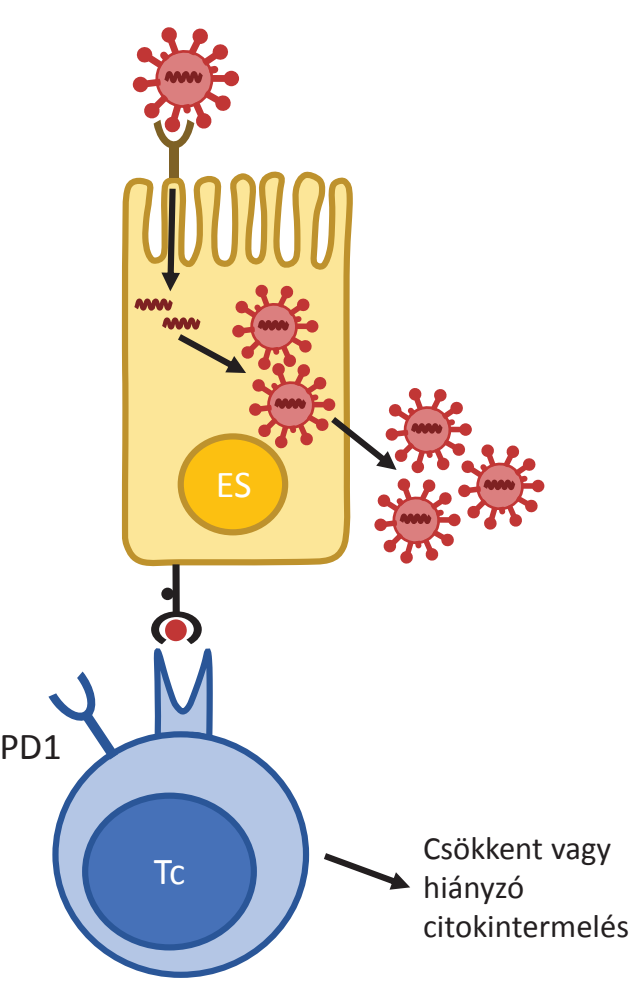

2. ábra

Citotoxikus T-sejtek múködése SARS-CoV-2-fertőzés során

A Fiziológiás múködés. A Tc-sejtek az MHCI-en történő prezentáció alapján felismerik és eliminálják a fertőzött sejteket, valamint a celluláris immunválaszt elősegítő citokineket termelnek, mely következményesen a kórokozó pusztulásához és csökkent ürítéséhez vezet

B Kimerülés. A késôi és túlzott aktiváció következtében a Tc-sejteken kifejezetté válik a gátló hatású PD-1 expressziója, és csökken vagy megszúnik citotoxikus hatásuk és citokintermelésük

ACE2 = az angiotenzinkonvertáló enzim 2-es típusa; ES = epithelsejt; IFN = interferon; $\mathrm{MHC}=$ fó hisztokompatibilitási komplex; PD-1 = programozott sejthalál fehérje-1; SARS-CoV-2 = súlyos akut légzőszervi szindrómát okozó koronavírus-2; Tc = citotoxikus T-sejt; TCR = T-sejt-receptor; TNF = tumornekrózis-faktor

testek miatt alakul ki [21]. Az ADE egyik típusa a nagy mennyiségü antigén-ellenanyag által képzett komplexek keletkezésével járó fokozott immunaktiváció, melynek során az immunkomplexek fóleg a kis erek falában lerakódva folyamatos gyulladást indukálnak, akadályozva a tüdőben a gázcserét. Az ADE másik típusa a fokozott fertőzés, melynek során a vírus a monocytákon, illetve makrofágokon - az ACE2, a CD147 és potenciálisan egyéb receptorok mellett - lévő antitestreceptorok segítségével fertőzi meg a sejteket, fokozott vírusreplikációt és súlyosabb betegséget okozva. A keletkező rengeteg antitest között pedig előfordulhatnak olyanok is, amelyek célt tévesztve saját fehérjékre irányulnak, így a SARS-CoV-2 legsúlyosabb eseteinek hátterében túlzott immunreakció és autoreaktív antitestek is állhatnak [22]. Autoreaktív ellenanyagok egészséges emberekben is képződhetnek ugyan, ezeket viszont az immunrendszer ellenőrzés alatt tartja, és eliminálja. A vírusfertőzés következtében diszfunkcionálissá vált immunrendszer azonban elvesztheti ezt a kontrollt, így az autoreaktív antitestek fennmaradhatnak, és hozzájárulhatnak a hosszú távú szervkárosodáshoz.
A SARS-CoV-2 tehát számos ponton beavatkozhat az ellene védekező immunrendszer összetett múködésébe, aminek következtében diszharmonikus, saját maga ellen irányuló immunválasz jöhet létre súlyos COVID-19megbetegedést okozva.

\section{A SARS-CoV-2-specifikus antitestek kimutatása}

Az antigénkimutatással egyidejúleg elindult az antitestek kimutatására irányuló tesztek fejlesztése is. Míg azonban az antigéntesztek vizsgálata során az engedélyező hatóság - részben jogosan kritizált - szigort tanúsított, addig a járvány előrehaladtával az antitestek engedélyezése immár rendkívüli gyorsasággal történt; a fejlődő országokban a források és az elérhető antigéntesztek szúkössége különösen megkönnyítette a szerológiai vizsgálatok terjedését [23], ami nem segítette azok minőségét [24]. E tényt mi sem bizonyítja jobban, mint számos teszt veszélyhelyzeti engedélyének későbbi visszavonása [25]. 


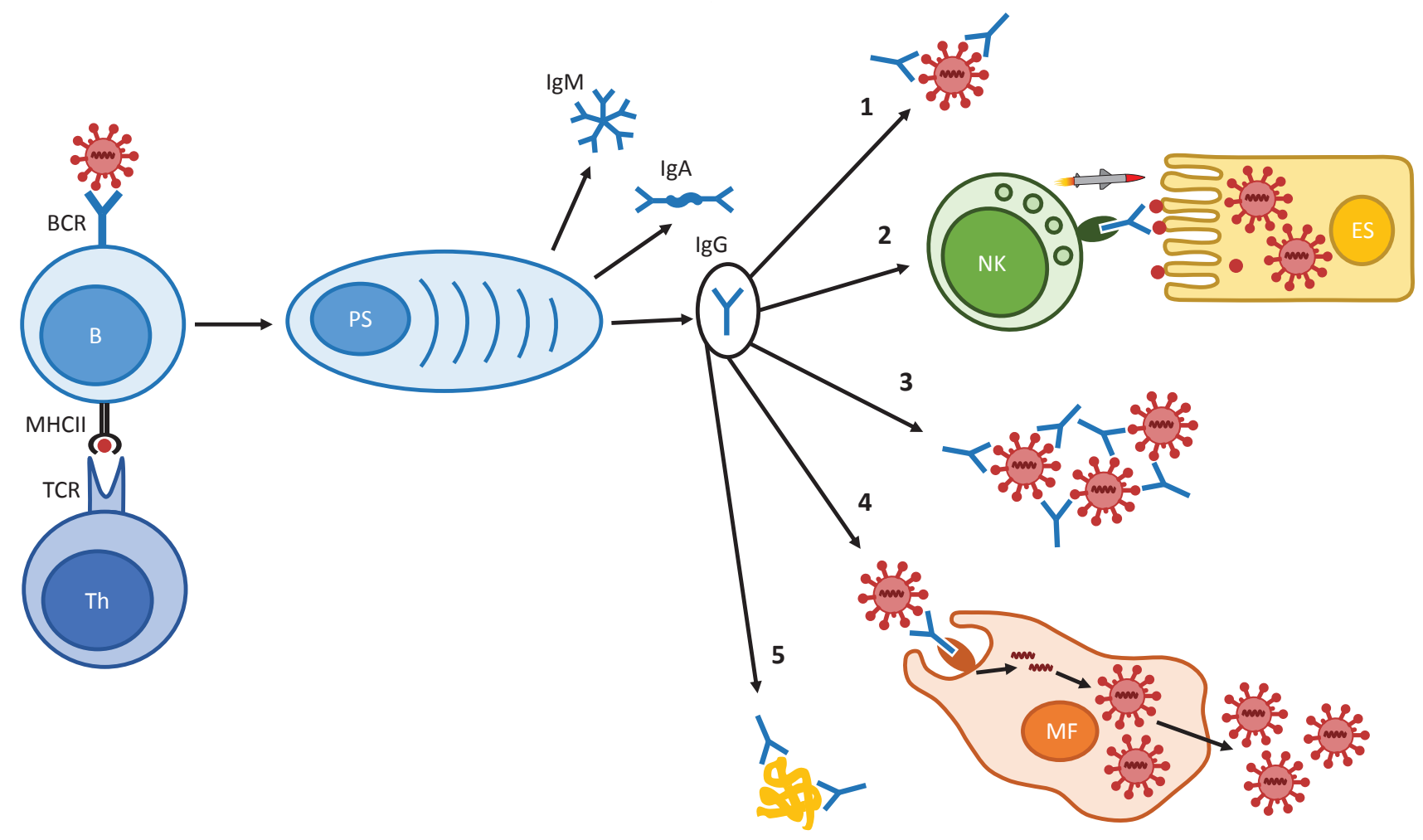

3. ábra

Az immunglobulin-termelés folyamata és az IgG funkciói. A B-sejtek maguk is múködhetnek antigénprezentáló sejtként, de aktiválásukhoz a Th-sejtek stimulációja is szükséges, melynek hatására először IgM-, majd IgA- vagy IgG-termelő plazmasejtekké differenciálódhatnak

1 Neutralizáció. Az IgG képes a SARS-CoV-2 semlegesítésére, például a sejtek fertőzéséhez szükséges S-fehérjék blokkolásával

2 ADCC. Az IgG révén az NK-sejtek kötődnek a fertőzött sejtekhez, és elpusztítják azokat a kórokozóval együtt

3 Komplex képződés. Az antigén és antitest alkotta immunkomplex gyulladáskeltő hatású, és aktiválja a komplementrendszert, mely túlzott mértékben káros következményekkel járhat

4 Fokozott fertőzés. Az IgG hozzájárulhat a vírusfelvétel növeléséhez antitest-specifikus receptoron keresztül, mely fokozott vírusürítéshez vezethet

5 Autoreaktív antitestek. A szervezet saját fehérjéire specifikus IgG hosszú távon fennmaradó önkárosító folyamatokat válthat ki

ADCC = ellenanyag-dependens sejt-citotoxicitás; $\mathrm{B}=\mathrm{B}$-sejt; $\mathrm{BCR}=\mathrm{B}$-sejt-receptor; ES = epithelsejt; IgA = immunglobulin-A; IgG = immunglobulin-G; $\mathrm{IgM}=$ immunglobulin-M; $\mathrm{MF}$ = makrofág; $\mathrm{MHC}=$ fó hisztokompatibilitási komplex; NK = természetes ölősejt; PS = plazmasejt; SARS-CoV-2 = súlyos akut légzőszervi szindrómát okozó koronavírus- $2 ; \mathrm{TCR}=\mathrm{T}$-sejt-receptor; Th = segítő T-sejt

A jelenleg a kereskedelmi forgalomban elérhető SARSCoV-2-antitest-szerológiai tesztek rendkívül eltérőek vizsgálati módszereikben: enzimet (ELISA), kemilumineszcenciát (CLIA), fluoreszcenciát (FIA) használó vagy áramláson alapuló (LFIA) immuntesztek; a detektált antitestekben: totális Ig, IgA vagy IgM; a vizsgált antigénben: tüskefehérje, nukleokapszid vagy receptorkötő domén (RBD); valamint a vizsgálati minta (szérum, plazma, teljes vér, ujjbegyvér) szempontjából [26]. Sajnálatos módon az eltérés hasonlóan szerteágazó a minőség tekintetében. Az Amerikai Egyesült Államokban a jelenleg elérhető tesztek validálása a pandémia miatt nem történt meg; az Élelmiszer- és Gyógyszer-engedélyeztetési Hivatal (FDA) veszélyhelyzeti engedélyével rendelkezö tesztek megalapozottsága rendkívül eltérő, a teszt múködésének bizonyítására szolgáló minták száma harminctól több ezerig terjed [27]. Az Európai Unió piacán számos állam, szervezet, egészségügyi szolgáltató és piaci szereplő abban a hitben vásárolt „európai megfelelő- ség” (CE) jelzésű termékeket, hogy ez a márkajel a feltétlen jó minőséget jelenti. A CE-jelzés alkalmazásához azonban jelenleg elégséges a gyártó mennyiségi és minőségi kritériumokhoz nem kötött saját értékelése, valamint az elöírt dokumentumok (megfelelőségi nyilatkozat, müszaki leírás, kézikönyv) benyújtása [28]. Az in vitro diagnosztikai eszközök szigorúbb szabályozását, a robusztus, minőség-ellenőrzés és javítás irányában előrelépést jelentő direktívák életbe léptetését - pontosan a pandémia miatt-2020. április 23-án elhalasztották [29].

Míg a mikrobiológia világában a szerológiai diagnózis hatékony eszköz - például a kullancsencephalitis kórjelzése esetében [30] -, addig a COVID-19 diagnosztikájában az antitestvizsgálatok helye, szerepe a kezdetektől kérdéses, és folyamatos változásban van. A szerológiai vizsgálatokra a pandémia kezdetén súlyos, kórházi kezelést igénylő esetekben került jellemzően sor, ennek ellenére az adatok már akkor elég széles skálán szóródtak [31-34]. Ezenfelül a tudományos kutatások minősége 
számos esetben kétségessé tette azok eredményeit [35], a képet pedig tovább árnyalták az enyhe tünetekkel jelentkező, illetve tünetmentes esetek [36]. Jelenlegi ismereteink alapján a szerokonverzió a tünetekkel járó COVID-19-megbetegedések többségében bekövetkezik a tünetek megjelenését követő három héten belül. A klinikai gyakorlatban az IgM- és az IgG-antitesttípusok vizsgálatára kerül sor, melyet a kereskedelmi forgalomban elérhetô tesztek átlagosan az IgM esetében a 7-12., az IgG esetében a 12-21. napon detektálnak [36-42]. Kifejezett összefüggés tapasztalható az IgGszérumszintek és a vírusclearance között a szerencsésebb kimenetelű esetekben, mely hatékony humorális adaptív védekezésre utal [43].

A szeropozitivitás azonban nem jelent védettséget: egyrészt a hatásos humorális immunválaszhoz hatékonyan neutralizáló antitestek szükségesek, másrészt az antitestek megjelenése káros is lehet (3. ábra). Az esetek egy részében (4-5\%) kimutatható mennyiségú antitest nem termelődik $[44,45]$, ugyanakkor az erős szerológiai válaszreakció csökkenő mértékben hónapokig is fennmaradhat [46]. A diagnosztikai célból történő kimutatás mellett az antitestek vizsgálata a különböző vakcinák hatékonyságának vizsgálatához is objektív eszközül szolgálhat, aminek folyományaként a szerológiai vizsgálómódszerek jelentősége nő, kutatásuk és fejlesztésük folyamatos [47], ideértve a kísérletesen megfigyelhetö specifikus IgA kimutatásának lehetőségét is [48].

\section{Lehetőségek és kihívások}

Minden krízis magában hordozza a fejlődés lehetőségét is. A COVID-19-járvány soha nem látott összefogást hozott a tudomány világában: az információáramlás felgyorsult, számos akadály elhárult, szabadon hozzáférhetővé váltak a SARS-CoV-2-vel foglalkozó kutatási eredmények. A laboratóriumi diagnosztika fejlődése e tárgykörben töretlen, s az idő előrehaladtával egyre többet tudunk a fertőzés és a kórokozó természetéről, valamint az egyes vizsgálati módszerek megbízhatóságáról. A koronavírusok esetében „elvárható” mutációk miatt az antigéndetektáló vizsgálatok pontos célzása, rendszeres felülvizsgálata kiemelten fontos. Az immunválasz oldaláról pedig laboratóriumi körülmények között már megjelent az intracelluláris kórokozókra jellemző T-sejtes immunválasz vizsgálata [49], mely a látens tuberkulózis diagnosztikájában eredményesen használt, IFN $\gamma$ termelést kimutató vizsgálatokhoz [50] hasonlóan a laboratóriumi gyakorlatban elterjedve áttörést hozhatna a hatékony celluláris immunválasz detektálhatóságában. A hétköznapokban a beteg érdekében pedig a legfontosabb a kritikus gondolkodás: megfelelő minőségú, megbízható vizsgálati módszer, eszköz és szervezeti egység választása, a lelet elhelyezése a páciens teljes kórtörténetében és értékelése a rendelkezésre álló valamennyi beteg- és járványügyi adat tükrében.
Anyagi támogatás: A közlemény megírása és a kapcsolódó kutatómunka anyagi támogatásban nem részesült.

Szerzői munkamegosztás: M. M.: A koncepciónak és az általános részeknek, a vírus útjának, az antitest-kimutatásnak és a záró soroknak a szövegezése. P. Z.: Az antigénkimutatás megfogalmazása. V. A.: Az immunológiai háttér biztosítása, az ábrák készítése és formai ellenőrzés. Minden szerző részt vett a cikk teljes szövegének nyelvi és szakmai szempontú javításában. A cikk végleges változatát valamennyi szerző elolvasta és jóváhagyta.

Érdekeltségek: A szerző́knek nincsenek érdekeltségeik.

\section{Irodalom}

[1] Váradi A, Ferenci T, Falus A. The coronavirus-induced COVID-19 pandemic. Previous experiences and scientific evidences at the end of March, 2020. [A koronavírus okozta COVID-19-pandémia. Korábbi tapasztalatok és tudományos evidenciák 2020. március végén.] Orv Hetil. 2020; 161: 644651. [Hungarian]

[2] Harrison AG, Lin T, Wang P. Mechanisms of SARS-CoV-2 transmission and pathogenesis. Trends Immunol. 2020; 41: 1100-1115.

[3] Kyrou I, Randeva HS, Spandidos DA, et al. Not only ACE2. The quest for additional host cell mediators of SARS-CoV-2 infection: neuropilin-1 (NRP1) as a novel SARS-CoV-2 host cell entry mediator implicated in COVID-19. Signal Transduct Target Ther. $2021 ; 6: 21$.

[4] Cevik M, Kuppalli K, Kindrachuk J, et al. Virology, transmission, and pathogenesis of SARS-CoV-2. BMJ 2020; 371: m3862.

[5] Althouse BM, Wenger EA, Miller JC, et al. Superspreading events in the transmission dynamics of SARS-CoV-2: opportunities for interventions and control. PLoS Biol. 2020; 18: e3000897.

[6] van Kampen JJ, van de Vijver DA, Fraaij PL, et al. Duration and key determinants of infectious virus shedding in hospitalized patients with coronavirus disease-2019 (COVID-19). Nat Commun. 2021; 12: 267.

[7] Liu Y, Yan LM, Wan L, et al. Viral dynamics in mild and severe cases of COVID-19. Lancet Infect Dis. 2020; 20: 656-657.

[8] Challener DW, Shah A, O'Horo JC, et al. Low utility of repeat real-time PCR testing for SARS-CoV-2 in clinical specimens. Mayo Clin Proc. 2020; 95: 1942-1945.

[9] Vandenberg O, Martiny D, Rochas O, et al. Considerations for diagnostic COVID-19 tests. Nat Rev Microbiol. 2021; 19: 171183.

[10] Rezaei M, Razavi Bazaz S, Zhand S, et al. Point of care diagnostics in the age of COVID-19. Diagnostics (Basel) 2020; 11:9.

[11] Rai P, Kumar BK, Deekshit VK, et al. Detection technologies and recent developments in the diagnosis of COVID-19 infection. Appl Microbiol Biotechnol. 2021; 105: 441-455.

[12] Machado BA, Hodel KV, Barbosa-Júnior VG, et al. The main molecular and serological methods for diagnosing COVID-19: an overview based on the literature. Viruses 2020; 13: 40.

[13] Mak GC, Cheng PK, Lau SS, et al. Evaluation of rapid antigen test for detection of SARS-CoV-2 virus. J Clin Virol. 2020; 129: 104500.

[14] Jendrny P, Schulz C, Twele F, et al. Scent dog identification of samples from COVID-19 patients - a pilot study. BMC Infect Dis. $2020 ; 20: 536$.

[15] Walker HJ, Burrell MM. Could breath analysis by MS could be a solution to rapid, non-invasive testing for COVID-19? Bioanalysis $2020 ; 12$ : 1213-1217. 
[16] Valkó A, Lőrincz M. Illustrated book of immunology. [Immunológiai illusztrációk könyve.) A/3 Nyomdaipari és Kiadói Szolgáltató Kft., Budapest, 2020. [Hungarian]

[17] Blanco-Melo D, Nilsson-Payant BE, Liu WC, et al. Imbalanced host response to SARS-CoV-2 drives development of COVID-19. Cell 2020; 181: 1036-1045.e9.

[18] Sokolowska M, Lukasik ZM, Agache I, et al. Immunology of COVID-19: mechanisms, clinical outcome, diagnostics, and perspectives. A report of the European Academy of Allergy and Clinical Immunology (EAACI). Allergy 2020; 75: 2445-2476.

[19] Diao B, Wang C, Tan Y, et al. Reduction and functional exhaustion of $\mathrm{T}$ cells in patients with coronavirus disease 2019 (COVID-19). Front Immunol. 2020; 11: 827.

[20] Lu L, Zhang H, Zhan M, et al. Antibody response and therapy in COVID-19 patients: what can be learned for vaccine development? Sci China Life Sci. 2020; 63: 1833-1849.

[21] Lee WS, Wheatley AK, Kent SJ, et al. Antibody-dependent enhancement and SARS-CoV-2 vaccines and therapies. Nat Microbiol. 2020; 5: 1185-1191.

[22] Khamsi R. Rogue antibodies could be driving severe COVID-19. Nature 2021; 590: 29-31.

[23] Peeling RW, Wedderburn CJ, Garcia PJ, et al. Serology testing in the COVID-19 pandemic response. Lancet Infect Dis. 2020; 20: e245-e249.

[24] Food and Drug Administration. Insight into FDA's revised policy on antibody tests: prioritizing access and accuracy. Available from: https://www.fda.gov/news-events/fda-voices/insightfdas-revised-policy-antibody-tests-prioritizing-access-and-accuracy [accessed: February 1, 2021].

[25] Food and Drug Administration. Certain COVID-19 serology/ antibody tests should not be used - letter to clinical laboratory staff and health care providers. Available from: https://www.fda. gov/medical-devices/letters-health-care-providers/certain-covid-19-serologyantibody-tests-should-not-be-used-letter-clinicallaboratory-staff-and [accessed: February 1, 2021].

[26] Theel ES, Slev P, Wheeler S, et al. The role of antibody testing for SARS-CoV-2: is there one? J Clin Microbiol. 2020; 58 : e00797-20.

[27] Food and Drug Administration. EUA authorized serology test performance. Available from: https://www.fda.gov/medicaldevices/coronavirus-disease-2019-covid-19-emergency-use-authorizations-medical-devices/eua-authorized-serology-test-performance [accessed: February 1, 2021].

[28] European Commission. CE marking. Available from: https:// ec.europa.eu/growth/single-market/ce-marking_en [accessed: February 1, 2021].

[29] European Commission. Medical devices - overview. Available from: https://ec.europa.eu/health/md_sector/overview_en [accessed: February 1, 2021].

[30] Holzmann H. Diagnosis of tick-borne encephalitis. Vaccine 2003; 21(Suppl 1): S36-S40.

[31] To KK, Tsang OT, Leung WS, et al. Temporal profiles of viral load in posterior oropharyngeal saliva samples and serum antibody responses during infection by SARS-CoV-2: an observational cohort study. Lancet Infect Dis. 2020; 20: 565-574.

[32] Zhao J, Yuan Q, Wang H, et al. Antibody responses to SARSCoV-2 in patients with novel coronavirus disease 2019. Clin Infect Dis. 2020; 71: 2027-2034.

[33] Lou B, Li TD, Zheng SF, et al. Serology characteristics of SARS$\mathrm{CoV}-2$ infection after exposure and post-symptom onset. Eur Resp J. 2020; 56: 2000763.
[34] Long QX, Liu BZ, Deng HJ, et al. Antibody responses to SARS CoV-2 in patients with COVID-19. Nat Med. 2020; 26: 845848.

[35] Lisboa Bastos M, Tavaziva G, Abidi SK, et al. Diagnostic accuracy of serological tests for COVID-19: systematic review and meta-analysis. BMJ 2020; 370: m2516.

[36] Jiang C, Wang Y, Hu M, et al. Antibody seroconversion in asymptomatic and symptomatic patients infected with severe acute respiratory syndrome coronavirus 2 (SARS-CoV-2). Clin Transl Immunology 2020; 9: el182.

[37] Staines HM, Kirwan DE, Clark DJ, et al. IgG seroconversion and pathophysiology in severe acute respiratory syndrome coronavirus 2 infection. Emerg Infect Dis. 2021; 27: 85-91.

[38] Fu Y, Li Y, Guo E, et al. Dynamics and correlation among viral positivity, seroconversion, and disease severity in COVID-19: a retrospective study. Ann Intern Med. 2020 Dec 8. Doi: 10.7326/M20-3337. [Epub ahead of print]

[39] Tuaillon E, Bolloré K, Pisoni A, et al. Detection of SARS-CoV-2 antibodies using commercial assays and seroconversion patterns in hospitalized patients. J Infect. 2020; 81: e39-e45.

[40] Gudbjartsson DF, Norddahl GL, Melsted P, et al. Humoral immune response to SARS-CoV-2 in Iceland. N Engl J Med. 2020; 383: 1724-1734.

[41] Sun B, Feng Y, Mo X, et al. Kinetics of SARS-CoV-2 specific $\mathrm{IgM}$ and IgG responses in COVID-19 patients. Emerg Microbes Infect. 2020; 9: 940-948.

[42] Xu X, Sun J, Nie S, et al. Seroprevalence of immunoglobulin M and $\mathrm{G}$ antibodies against SARS-CoV-2 in China. Nat Med. 2020; 26: 1193-1195.

[43] Iwasaki A, Yang Y. The potential danger of suboptimal antibody responses in COVID-19. Nat Rev Immunol. 2020; 20: 339341.

[44] Baron RC, Risch L, Weber M, et al. Frequency of serological non-responders and false-negative RT-PCR results in SARSCoV-2 testing: a population-based study. Clin Chem Lab Med. 2020; 58: 2131-2140

[45] Oved K, Olmer L, Shemer-Avni Y, et al. Multi-center nationwide comparison of seven serology assays reveals a SARS-CoV-2 nonresponding seronegative subpopulation. EClinicalMedicine 2020; 29: 100651 .

[46] Röltgen K, Powell AE, Wirz OF, et al. Defining the features and duration of antibody responses to SARS-CoV-2 infection associated with disease severity and outcome. Sci Immunol. 2020; 5: eabe 0240 .

[47] Jeyanathan M, Afkhami S, Smaill F, et al. Immunological considerations for COVID-19 vaccine strategies. Nat Rev Immunol. 2020; 20: 615-632.

[48] Chao YX, Rötzschke O, Tan EK. The role of IgA in COVID-19. Brain Behav Immun. 2020; 87: 182-183.

[49] Dan JM, Mateus J, Kato Y, et al. Immunological memory to SARS-CoV-2 assessed for up to 8 months after infection. Science 2021; 371: eabf4063.

[50] Pai M, Denkinger CM, Kik SV, et al. Gamma interferon release assays for detection of Mycobacterium tuberculosis infection. Clin Microbiol Rev. 2014; 27: 3-20.

(Medgyaszai Melinda dr., Budapest, Korányi Frigyes út 1., 1121 e-mail: medgyaszai.m@koranyi.hu)

A cikk a Creative Commons Attribution 4.0 International License (https://creativecommons.org/licenses/by-nc) feltételei szerint publikált Open Access közlemény, melynek szellemében a cikk bármilyen médiumban szabadon felhasználható, megosztható és újraközölhető, feltéve, hogy az eredeti szerző és a közlés helye, illetve a CC License linkje és az esetlegesen végrehajtott módositások feltüntetésre kerülnek. 